- FINANSE I PRAWO FINANSOWE.

- Journal of Finance and Financial Law •

Marzec/March 2018 • vol. 1(17): 49-65

https://doi.org/10.18778/2391-6478.1.17.05

\title{
INSTYTUCJA BUDŻETU OBYWATELSKIEGO JAKO NARZĘDZIA ROZWOJU SAMORZĄDU LOKALNEGO
}

\author{
Daria Rybińska \\ Wydział Zarządzania \\ Uniwersytet Warszawski
}

\section{Streszczenie}

Budżet obywatelski jest uważany za jedno z najlepszych narzędzi, uwzględniających preferencje mieszkańców w procesie zarządzania środkami publicznymi. Jest on instrumentem, pozwalającym mieszkańcom na współdecydowanie o kierunku wydatkowania środków z budżetu samorządu lokalnego. W artykule podjęto próbę określenia wpływu instytucji budżetu obywatelskiego na rozwój jednostki samorządu terytorialnego.

W tym celu poddano analizie cztery edycje budżetu obywatelskiego miasta Łodzi, przeprowadzone w latach 2013-2016. Zwrócono szczególną uwagę na zasady przeprowadzania budżetu, rodzaje zrealizowanych zadań oraz kierunki wydatkowania środków. Na koniec zaprezentowano wnioski płynące z przeprowadzonej analizy, które potwierdzają, iż budżet obywatelski jest narzędziem wpływającym na rozwój samorządu lokalnego.

Słowa kluczowe: budżet obywatelski, partycypacja społeczna, samorząd terytorialny.

JEL Class: H70, H72, H79. 


\section{WPROWADZENIE}

Uchwalanie budżetu obywatelskiego, choć formalnie nie stanowi obowiązku władz jednostek samorządu terytorialnego, jest coraz częściej stosowaną przez nie praktyką. Budżet partycypacyjny (potocznie nazywany również budżetem obywatelskim) jest pojęciem, które nie ma definicji formalnoprawnej. Zgodnie z definicją Banku Światowego, budżet obywatelski to proces, w wyniku którego obywatele przedstawiają swoje żądania i priorytety obywatelskie oraz wpływają na strukturę wydatków budżetowych poprzez dyskusję i negocjacje [Wampler 2007: 27]. Innymi słowy, budżet partycypacyjny to oddolny proces definiowania priorytetów budżetowych (wydatków) i wskazywanie przez mieszkańców, które inwestycje, inicjatywy należy realizować we wspólnocie samorządowej w danym roku [Dolewka 2015: 63].

Po raz pierwszy rozwiązanie w postaci budżetu obywatelskiego wprowadzono w brazylijskim mieście Porto Alegre w latach 80. XX wieku. Był on odpowiedzią na problemy społeczno-ekonomiczne miasta, m.in. pogłębiające się ubóstwo, rosnącą przestępczość oraz wykluczenie społeczne [Dias 2014: 9]. Miał na celu włączenie mieszkańców w proces zarzadzania środkami publicznymi, a co za tym idzie, zwiększenie transparentności wydatkowania środków oraz zbudowanie relacji pomiędzy władzami publicznymi a mieszkańcami [Rytel-Warzocha 2010: 93]. Ogromny sukces takiej formy budżetu sprawił, że zyskał on popularność nie tylko w Ameryce Południowej, ale także na innych kontynentach, szczególnie po roku 1996, kiedy na konferencji ONZ w Stambule uznano budżet partycypacyjny Porto Alegre za jedno z 42 najlepszych rozwiązań w zakresie zarzadzania miastami [Goldfrank 2007: 93].

W Polsce pierwszy budżet obywatelski powstał stosunkowo późno, bo dopiero w 2011 roku. Prekursorem wdrożenia idei budżetu obywatelskiego było miasto Sopot. W ślad za Sopotem podążyły inne polskie miasta (np. Gorzów Wielkopolski, Poznań, Zielona Góra), powiaty (gostyński, wągrowiecki), czy województwa (np. wielkopolskie) [Łukomska-Szarek 2014: 141]. W 2013 roku budżet obywatelski wprowadziły kolejne polskie miasta, między innymi Łódź, która przeznacza na realizację budżetu obywatelskiego jedną z największych kwot w Polsce [Kalisiak-Mędelska 2016: 104].

Budżet obywatelski, jak każda inicjatywa angażująca obywateli w życie publiczne, ma zarówno swoich zwolenników, jak i przeciwników. Zwolennicy idei budżetu obywatelskiego podkreślają jej pozytywny wpływ na rozwój miasta, alokację środków w obszary dotychczas zaniedbywane przez władze samorządowe oraz aktywizację mieszkańców w obszarze wydatkowania publicznych pieniędzy. Przeciwnicy zaś twierdzą, że jest to jedynie moda, potęgowana przez 
medialny rozgłos, której jedyną korzyścią jest zwiększenie prawdopodobieństwa reelekcji władz samorządu.

Biorąc za punkt wyjścia niniejsze rozważania, postanowiono poddać ocenie budżet obywatelski miasta Łodzi w latach 2013-2016 w celu określenia wpływu instytucji budżetu partycypacyjnego na rozwój miasta. Dokonując analizy położono nacisk na obowiązujące zasady przeprowadzania budżetu, rodzaje projektów poddanych pod głosowanie oraz kierunki wydatkowania środków.

Artykuł opracowano na podstawie zdywersyfikowanych źródeł literaturowych: pozycji książkowych, publikacji naukowych oraz materiałów pomocniczych. W części empirycznej artykułu wykorzystano dane opublikowane przez Urząd Miasta Łodzi oraz Główny Urząd Statystyczny.

\section{ISTOTA I ZASADY BUDŻETU PARTYCYPACYJNEGO}

Budżet partycypacyjny, jako zjawisko, które pojawiło się w Polsce dopiero w ostatnich latach, nie doczekało się legalnej definicji. Leksykon budżetowy określa budżet obywatelski jako „nieformalny zwrot określający wydzieloną część budżetu samorządu terytorialnego (najczęściej budżetu miasta), w ramach którego wyznaczona odgórnie kwota wydatków przeznaczona jest na inicjatywy i projekty inwestycyjne bezpośrednio zgłaszane przez społeczeństwo lokalne (indywidualnie lub przez odpowiednie organizacje)" [www 1]. Literatura przedmiotu definiuje zaś budżet obywatelski jako „proces decyzyjny, w ramach którego mieszkańcy współtworzą budżet danej jednostki, tym samym decydując o dystrybucji określonej puli środków pieniężnych" [Kębłowski 2013: 8] lub ,proces, poprzez który obywatele przedstawiają swoje żądania i priorytety obywatelskie oraz wpływają na strukturę wydatków budżetowych poprzez dyskusję i negocjacje" [Wampler 2007: 21]. Na postawie zaprezentowanych powyżej definicji można więc stwierdzić, że budżet obywatelski jest demokratycznym procesem dyskusji i podejmowania decyzji co do przeznaczenia środków publicznych z udziałem obywateli (mieszkańców) [Kalisiak-Mędelska 2016: 106]. Budżet partycypacyjny może być tworzony na różnych szczeblach administracyjnych: począwszy od poziomu regionalnego, poprzez poziom gminy i miasta, aż do poziomu dzielnicy lub osiedla [Serzysko 2015: 8]. Budżet partycypacyjny może również zostać wykorzystany do tworzenia budżetu pojedynczej instytucji publicznej.

Podstawą prawną wprowadzania budżetów obywatelskich w jednostkach samorządu terytorialnego jest artykuł 5a Ustawy o samorządzie gminnym, na mocy którego w wypadkach przewidzianych Ustawą oraz w innych sprawach ważnych dla gminy na jej terytorium mogą być przeprowadzane konsultacje 
z mieszkańcami [Kraszewski i Mojkowski 2014: 8]. Budżet obywatelski w Polsce jest więc organizowany na nieformalnych zasadach jako konsultacje społeczne [Sorychta-Wojszczyk 2015: 423]. Zasady i tryb przeprowadzania konsultacji społecznych określa uchwała rady gminy. Nie należy jednak utożsamiać konsultacji społecznych z budżetem obywatelskim. Konsultacje społeczne z reguły nie są wiążące dla władz. W praktyce oznacza to, że władze samorządowe mogą, ale nie muszą wziąć pod uwagę opinii mieszkańców. Inaczej jest w przypadku budżetu obywatelskiego, gdzie decyzje mieszkańców mają charakter wiążący. Mieszkańcy muszą mieć pewność, że wybrane przez nich projekty zostaną zrealizowane w następnym roku budżetowym $\mathrm{z}$ wyodrębnionych na ten cel środków.

Budżet partycypacyjny charakteryzuje się pewnymi zasadami, które muszą być obowiązkowo spełnione, aby zapewnić autentyczny udział mieszkańców w zarządzaniu daną jednostką samorządu terytorialnego. Podstawowe zasady budżetu partycypacyjnego to [Szaranowicz-Kusz 2014: 10]:

1) decyzja mieszkańców jest wiążąca;

2) decyzja mieszkańców dotyczy jasno określonych i ograniczonych środków finansowych;

3) budżet partycypacyjny jest organizowany cyklicznie;

4) realizacja budżetu partycypacyjnego opiera się na przejrzystych regułach;

5) w procesie są zaplanowane dyskusje między mieszkańcami, a nie tylko głosowanie;

6) należy zadbać o powszechność udziału mieszkańców w budżecie partycypacyjnym;

7) należy wystrzegać się uznaniowości administracji w trakcie procesu.

Zachowanie zasad przedstawionych powyżej jest niezwykle istotne. Dzięki jasno określonym regułom budowane jest zaufanie pomiędzy mies zkańcami a władzami samorządowymi. Niezwykle ważne jest, aby budżet obywatelski nie był jednorazowym gestem władz samorządowych w kierunku mieszkańców [Po co nam ..., dostęp: 29.08.2013]. Powinien również dawać mieszkańcom możliwość kształtowania długoterminowych celów samorządu oraz priorytetów jego polityki [Aleksandrowicz, dostęp: 11.06.2013]. Zasady te nie stanowią zamkniętego zbioru. Przy tworzeniu budżetu obywatelskiego należy pamiętać, że ma on być narzędziem, które w rzeczywisty sposób angażuje mieszkańców w życie publiczne i musi się kierować takimi zasadami, aby to zaangażowanie w pełni umożliwić. 


\section{BUDŻET PARTYCYPACYJNY ŁODZI - ANALIZA}

Budżet obywatelski w Łodzi jest największym budżetem tego typu wdrożonym przez polskie władze lokalne. W trzech z czterech dotychczas zorganizowanych edycji budżetu obywatelskiego w latach 2014, 2015 i 2016 jego wartość wynosiła 40 milionów złotych. Każdy mieszkaniec miasta uprawniony do głosowania może wybrać 10 projektów. Połowa z nich dotyczy zadań lokalnych, druga połowa dotyczy projektów ogólnomiejskich. Zadania lokalne to takie zadania, które są skierowane do mieszkańców każdego z wydzielonych obszarów miasta. Zadania ogólnomiejskie natomiast odpowiadają potrzebom mieszkańców więcej niż jednego obszaru miasta bądź lokalizacja zadania nie jest przydzielona do żadnego konkretnego obszaru.

$\mathrm{Z}$ uwagi na fakt, iż nie ma jednego uniwersalnego modelu wdrażania budżetu obywatelskiego w polskich miastach, proces realizacji budżetu obywatelskiego w Łodzi został dostosowany do indywidualnych potrzeb miasta, z zachowaniem ogólnych zasad, jakimi powinien kierować się budżet obywatelski. Cechy budżetu partycypacyjnego w Lodzi przedstawiono w tab. 1 .

Analizując informacje zawarte $\mathrm{w}$ tab. 1 warto zwrócić uwagę na dwie istotne kwestie: etap weryfikacji zgłoszonych projektów oraz osoby uprawnione do głosowania. W przypadku weryfikacji projektów można zauważyć brak kontroli projektów w kwestii merytorycznej. Skutkuje to realizacją w ramach budżetu obywatelskiego, obok dużych, istotnych z punktu widzenia rozwoju miasta projektów, także tych projektów dotyczących bardzo wąskiej grupy mieszkańców oraz o krótkim czasie użyteczności. Brak merytorycznej weryfikacji projektów trudno jest jednoznacznie ocenić. $Z$ jednej strony sprawia, że władze miasta nie mają kontroli nad celowością wydatkowania środków z budżetu obywatelskiego, z drugiej strony jednak takie rozwiązanie podkreśla niezależność budżetu obywatelskiego i jego prospołeczny charakter.

Jeżeli chodzi o osoby uprawnione do głosowania, zasady budżetu obywatelskiego określają, że jest to mieszkaniec miasta, który ukończył 16 lat. Ważne jest, że nie musi być to osoba zameldowana w mieście. Daje to możliwość głosowania grupom społecznym związanym $\mathrm{z}$ miastem, ale zameldowanym $\mathrm{w}$ innych miejscowościach, na przykład studentom.

Projekty realizowane $\mathrm{w}$ ramach budżetu obywatelskiego Łodzi można podzielić na kategorie, w zależności od zakresu działań, którego te projekty dotyczą. Są to następujące kategorie:

1) Edukacja/dzieci/młodzież - są to głównie projekty infrastrukturalne, dotyczące modernizacji budynków szkół i przedszkoli, sal gimnastycznych placów zabaw, tworzenia pracowni tematycznych, a także komputeryzacji i doposażenia klas. 
Tabela 1. Cechy budżetu partycypacyjnego w Łodzi

\begin{tabular}{|l|l|}
\hline \multicolumn{1}{|c|}{ Wyszczególnienie } & \multicolumn{1}{|c|}{ Cechy } \\
\hline $\begin{array}{l}\text { Pomioty, które mogą zgłaszać } \\
\text { projekty }\end{array}$ & $\begin{array}{l}\text { Mieszkańcy miasta - osoby fizyczne. Wymagane jest popar- } \\
\text { cie minimum 15 mieszkańców (poza autorami projektu). }\end{array}$ \\
\hline $\begin{array}{l}\text { Konsultacje społeczne w sprawie } \\
\text { budżetu }\end{array}$ & Wymagane \\
\hline Przeznaczenie środków & $\begin{array}{l}\text { Projekty w ramach zadań znajdujących się w zakresie } \\
\text { zadań własnych miasta, które są możliwe do realizacji } \\
\text { w trakcie jednego roku budżetowego }\end{array}$ \\
\hline Podział zadań & Zadania lokalne i ogólnomiejskie \\
\hline Wielkość środków wydzielonych & $\begin{array}{l}\text { 40 mln zł, w tym: } \\
\text { 30 mln zł na zadania lokalne (6 mln zł na każdy wydzielony } \\
\text { obszar miasta) } \\
\text { 10 mln zł na zadania ogólnomiejskie }\end{array}$ \\
\hline ramach budżetu & $\begin{array}{l}\text { 1) kompletność i poprawność wniosku pod względem } \\
\text { formalnym } \\
\text { 2) zgodność z zakresem zadań własnych miasta } \\
\text { 3) zgodność z prawem } \\
\text { 4) umiejscowienie na gruntach należących do miasta } \\
\text { 5) możliwości realizacji w ciągu jednego roku budżetowego } \\
\text { 6) limit środków w ramach wskazanych grup zadań } \\
\text { 7) celowość realizacji zadania w kontekście ustawowych } \\
\text { wymogów w zakresie gospodarności }\end{array}$ \\
\hline $\begin{array}{l}\text { Kryteria weryfikacji zgłoszonychość dokonywania zmian } \\
\text { projektów projektach }\end{array}$ & Wyłącznie za zgodą autora \\
\hline Osoby uprawnione do głosowania & Mieszkańcy, którzy ukończyli 16 lat \\
\hline Głosowanie & $\begin{array}{l}\text { Za pośrednictwem formularza do głosowania w formie } \\
\text { papierowej lub elektronicznej. Wybierane są zadania } \\
\text { z największą liczbą głosów do momentu wyczerpania puli } \\
\text { środków przewidzianych na dany obszar miasta. }\end{array}$ \\
\hline
\end{tabular}

Źródło: Kalisiak-Mędelska [2016: 109].

2) Infrastruktura drogowa i komunikacyjna - są to projekty z zakresu budowy i modernizacji dróg, chodników, sygnalizacji świetlnej itp.

3) Sport i rekreacja - w tej grupie znajdują się projekty dotyczące budowy i modernizacji boisk i ogólnodostępnych obiektów sportowych, a także organizacji imprez plenerowych.

4) Infrastruktura komunalna i bezpieczeństwo - są to projekty dotyczące np. koszy na odpady w miejscach publicznych lub sieci monitoringu.

5) Tereny zielone i ochrona środowiska - są to wszelkie działania związane $\mathrm{z}$ rewitalizacją parków i skwerów miejskich. 
6) Kultura i dziedzictwo - w tej grupie znajdują się głównie projekty dotyczące doposażenia i komputeryzacji miejskich bibliotek.

7) Zdrowie i pomoc społeczna - są to projekty z zakresu modernizacji miejskich przychodni, dostosowania ich do potrzeb osób niepełnosprawnych oraz doposażenia w niezbędny sprzęt.

8) Infrastruktura rowerowa - głównie są to projekty dotyczące roweru miejskiego oraz budowy i modernizacji ścieżek oraz parkingów rowerowych.

9) Inne - są to wszystkie pozostałe projekty, nie zaliczające się do żadnej z ww. grup, na przykład projekty dotyczące pomocy zwierzętom.

Dotychczas zrealizowane cztery edycje budżetu obywatelskiego w Lodzi pozwoliły na rozdysponowanie przez mieszkańców łącznie $140 \mathrm{mln}$ zł. Środki te w całości pochodzą z budżetu miasta - konstrukcja budżetu obywatelskiego nie dopuszcza wkładu własnego projektodawców ani środków pochodzących z innych źródeł. Udział budżetu obywatelskiego w budżecie miasta Łodzi przedstawia tab. 2.

Tabela 2. Budżet obywatelski a budżet miasta Łodzi

\begin{tabular}{|l|c|c|c|c|}
\hline & 2013 & 2014 & 2015 & 2016 \\
\hline $\begin{array}{l}\text { Kwota budżetu obywa- } \\
\text { telskiego (zł) }\end{array}$ & 20000000 & 40000000 & 40000000 & 40000000 \\
\hline Budżet miasta (zł) & 4120493372 & 4111775641 & 4169712325 & 3558269429 \\
\hline $\begin{array}{l}\text { Wydatki majątkowe } \\
\text { budżetu miasta (zł) }\end{array}$ & 1316352370 & 1315429859 & 1300753646 & 623231847 \\
\hline Liczba ludności & 722000 & 705000 & 700000 & 695000 \\
\hline Liczba głosujących & 129008 & 174834 & 135000 & 204468 \\
\hline $\begin{array}{l}\text { Udział budżetu obywa- } \\
\text { telskiego w budżecie } \\
\text { miasta (\%) }\end{array}$ & 0,49 & 0,97 & 0,96 & 1,1 \\
\hline $\begin{array}{l}\text { Kwota budżetu obywa- } \\
\text { telskiego przypadająca }\end{array}$ & 28 & 57 & 57 & 58 \\
na 1 mieszkańca (zł)
\end{tabular}
[www4].

Źródło: opracowanie własne na podstawie danych UMŁ [www2, www3] oraz danych GUS

Budżet obywatelski tylko w 1 edycji wynosił $20 \mathrm{mln}$ zł, od 2 edycji zwiększył się dwukrotnie i niezmiennie wynosi $40 \mathrm{mln}$ zł. Stanowi około 1\% całego budżetu miasta.

W przeliczeniu na 1 mieszkańca, budżet obywatelski był największy w 2016 roku i wyniósł 58 zł. Jest to ponad dwukrotnie więcej niż w pierwszej edycji budżetu oraz o 1 zł więcej niż w dwóch następnych edycjach. Tendencja 
wzrostowa nie powinna jednak napawać optymizmem, ponieważ przy niezmiennej kwocie budżetu obywatelskiego świadczy ona o wyludnianiu się miasta.

Projekty do budżetu obywatelskiego może zgłaszać każdy mieszkaniec miasta. Takie rozwiązanie wpływa nie tylko na różnorodność projektów zgłaszanych do każdej z edycji budżetu, ale także na ich ilość. Liczbę zadań zgłoszonych do dotychczasowych edycji budżetu przedstawia wykres 1 .

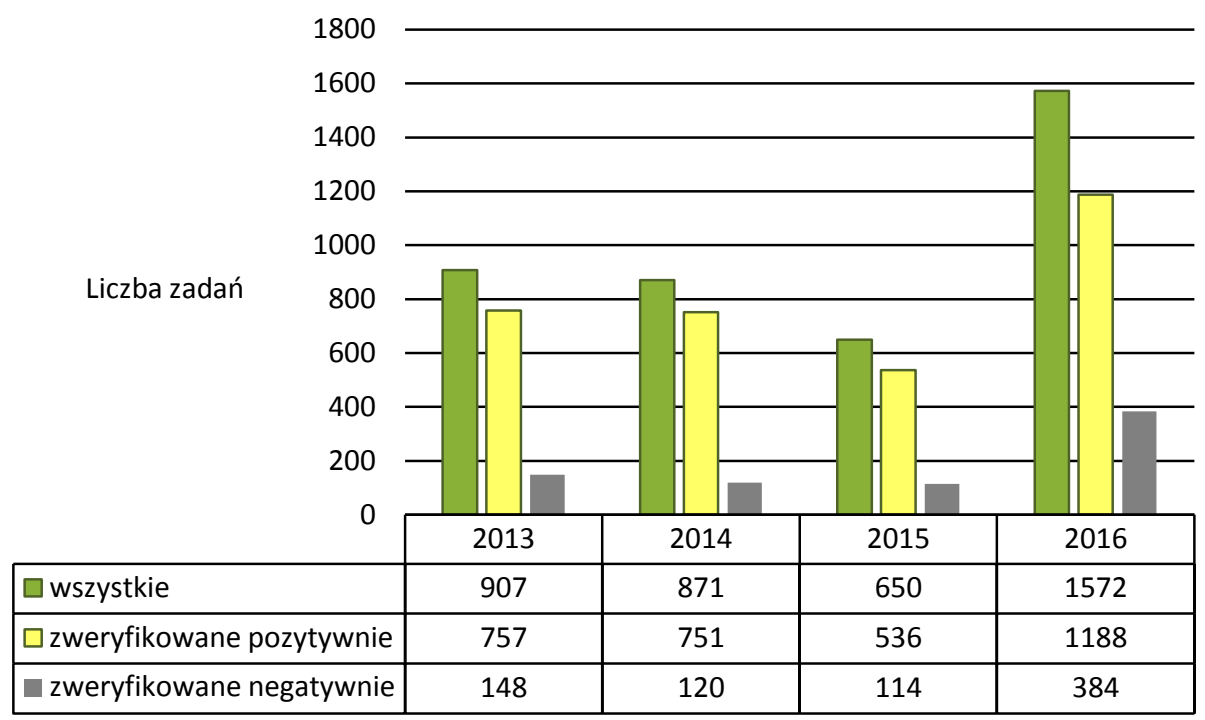

$\square$ wszystkie $\square$ zweryfikowane pozytywnie $\quad$ zweryfikowane negatywnie

Wykres 1. Zadania zgłoszone do budżetu obywatelskiego Łodzi

Źródło: opracowanie własne na podstawie danych UMŁ [www2].

W pierwszej edycji budżetu obywatelskiego w 2013 roku mieszkańcy zgłosili ponad 900 zadań, z czego około $16 \%$ zostało zweryfikowane negatywnie przez Urząd Miasta $\mathrm{z}$ uwagi na błędy formalne we wnioskach. W dwóch kolejnych edycjach budżetu można zauważyć stopniowe słabnące zainteresowanie projektodawców - w 3 edycji zgłoszono aż o 250 wniosków mniej niż w 1 edycji. Udział wniosków odrzucanych z uwagi na błędy we wnioskach kształtował się na podobnym poziomie i wynosił odpowiednio $14 \%$ dla 2 edycji i $18 \%$ dla 3 edycji. Dopiero 4 edycja budżetu przyniosła znaczący wzrost liczby zadań zgłaszanych przez mieszkańców. W porównaniu do wcześniejszej edycji budżetu z 2015 roku, zgłoszono ponad dwukrotnie więcej zadań. Do tak dużego wzrostu przyczyniły się zmiany poczynione przez Urząd Miasta, czyli zaangażowanie jednostek pomocniczych - osiedli oraz ograniczenie kwoty pojedynczego zada- 
nia. Mieszkańcy zgłaszali mniejsze projekty, dedykowane ich najbliższemu otoczeniu, dlatego więcej osób zdecydowało się na zgłoszenie swojego pomysłu do budżetu. W tej edycji zauważalna jest również większa kontrola wniosków - aż $25 \%$ wszystkich projektów została odrzucona w procesie weryfikacji.

Projekty, które pozytywnie przeszły proces weryfikacji są poddawane pod głosowanie. Realizowane są projekty aż do wyczerpania puli środków przeznaczonych na dany obszar. W sytuacji, gdy pozostałe do rozdysponowania środki są mniejsze niż koszt następnego projektu z największą liczbą głosów, do realizacji przechodził pierwszy z projektów, którego koszt mieścił się w pozostałej kwocie budżetu. Zadania wybrane w poszczególnych edycjach budżetu obywatelskiego wraz z ich podziałem na dzielnice przedstawia wykres 2.

Analizując informacje przedstawione na wykresie 2 można zaobserwować, że liczba zadań wybieranych do realizacji z roku na rok systematycznie rosła. W 4 edycji budżetu do realizacji wybrano ponad 2-krotnie więcej projektów niż w edycji ją poprzedzającej. Trzeba jednak pamiętać, że w ostatniej, analizowanej edycji pojedyncze projekty mają dużo mniejszą wartość szacunkową, dlatego przy takiej samej kwocie budżetu obywatelskiego można zrealizować dużo więcej zadań.

Na wykresie 2 przedstawiono także preferencje obszarów miasta w wyborze zadań. O ile w pierwszej edycji nie widać między nimi dużych dysproporcji w liczbie wybieranych zadań, o tyle w następnych edycjach można zauważyć, że mieszkańcy Śródmieścia preferują wybór mniejszej liczby zadań, ale o większej wartości. Z kolei mieszkańcy Polesia odwrotnie - tam w każdej edycji budżetu wybierana była największa ilość zadan do realizacji. W pozostałych obszarach wartości te kształtują się na podobnym poziomie i są zależne od edycji budżetu.

Dokonując podziału projektów wybranych do realizacji w poszczególnych edycjach budżetu obywatelskiego na wcześniej zaproponowane kategorie można wywnioskować preferencje mieszkańców dotyczące rodzaju wybieranych projektów oraz zmiany tych preferencji w poszczególnych edycjach budżetu. Analizę liczby projektów wraz z podziałem na poszczególne kategorie i dynamik zmian przedstawia wykres 3 .

Informacje zawarte na wykresie 3 pokazują, że wśród najczęściej realizowanych projektów przodują te z zakresu edukacji, dzieci i młodzieży. Dynamiczny wzrost $\mathrm{w}$ ostatniej edycji zaliczyły projekty $\mathrm{z}$ zakresu infrastruktury drogowej i komunikacyjnej, kultury oraz sportu i rekreacji. Od ostatniej, rekordowej edycji wzrosła także ilość realizowanych projektów z zakresu infrastruktury komunalnej oraz rowerowej, mimo, że we wcześniejszych latach ich udział w liczbie realizowanych projektów był dość niewielki. Spadek odnotowały zaś projekty z zakresu zdrowia i pomocy społecznej - w pierwszych edycjach były drugimi najczęściej realizowanymi projektami, w ostatniej edycji ich udział kształtował się na średnim poziomie. 


\section{Zadania wybrane do realizacji}

250

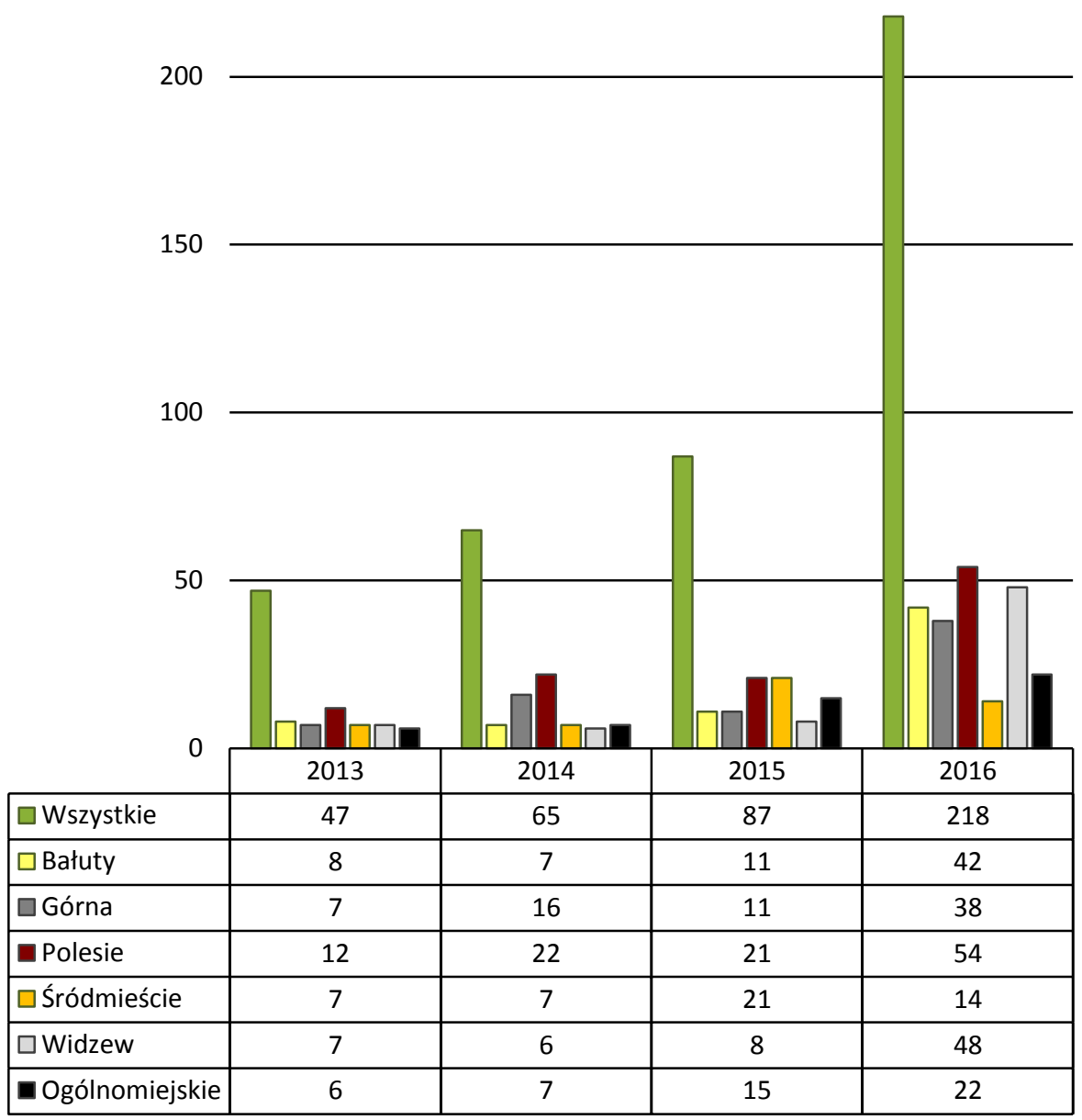

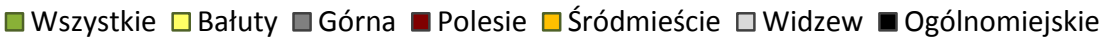

Wykres 2. Zadania budżetu obywatelskiego, wybrane do realizacji, ujęcie terytorialne

Źródło: opracowanie własne na podstawie danych UMŁ [www2]. 


\section{Projekty wbyrane do realizacji}

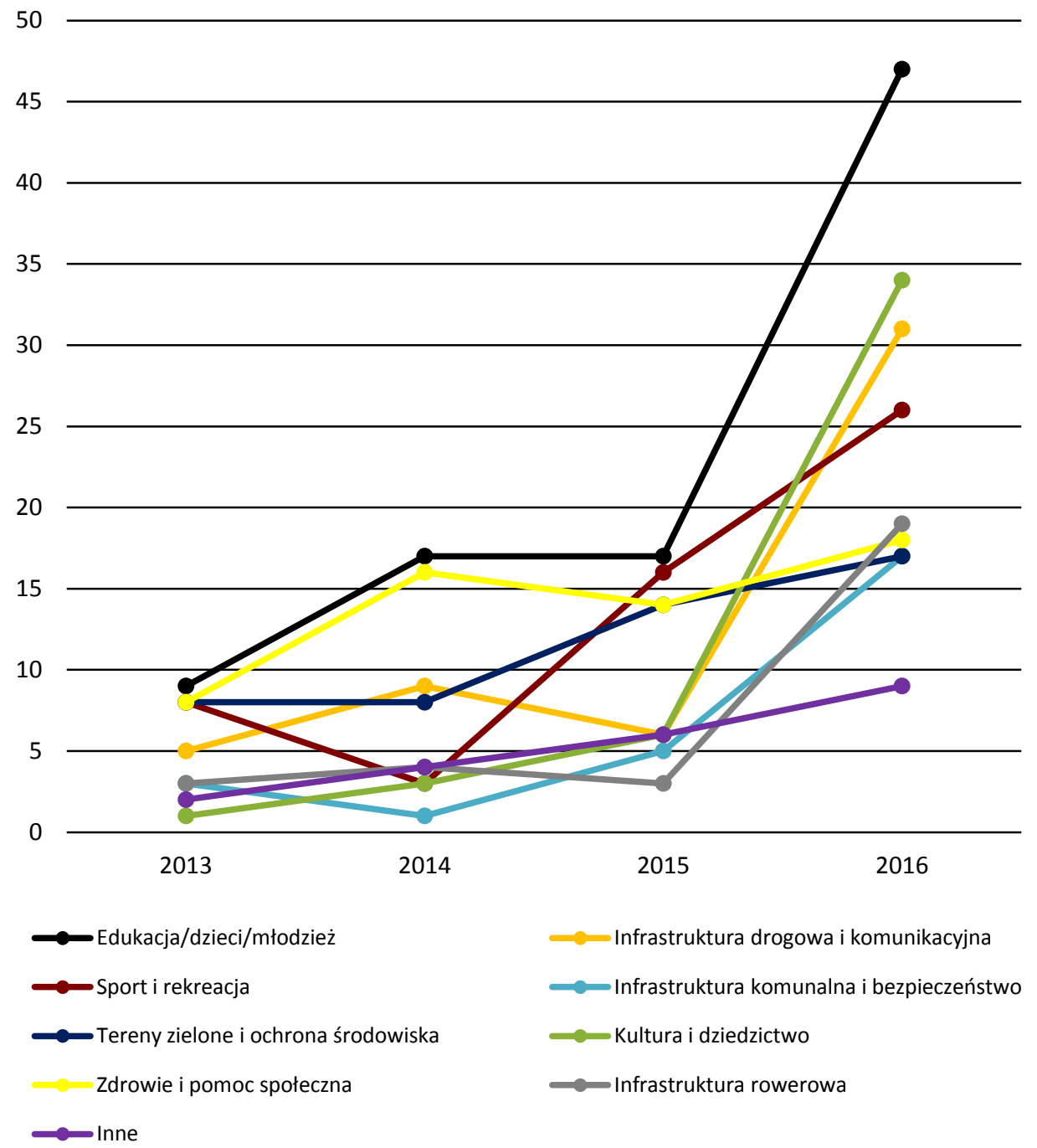

Wykres 3. Projekty wybrane do realizacji, ujęcie przedmiotowe

Źródło: opracowanie własne na podstawie danych UMŁ [www2]. 
Liczba realizowanych projektów nie daje jednak pełnego obrazu, w jakim stopniu zrealizowane projekty wpłynęły na rozwój poszczególnych obszarów, ponieważ projekty zgłaszane do budżetu obywatelskiego mają różną wartość - od kilkuset do nawet kilku milionów zł. Warto więc dokonać podobnej analizy, tym razem jednak za punkt wyjścia przyjmując wartość zrealizowanych projektów. Taką analizę przedstawia wykres 4.

Wartość projektów wybranych do realizacji

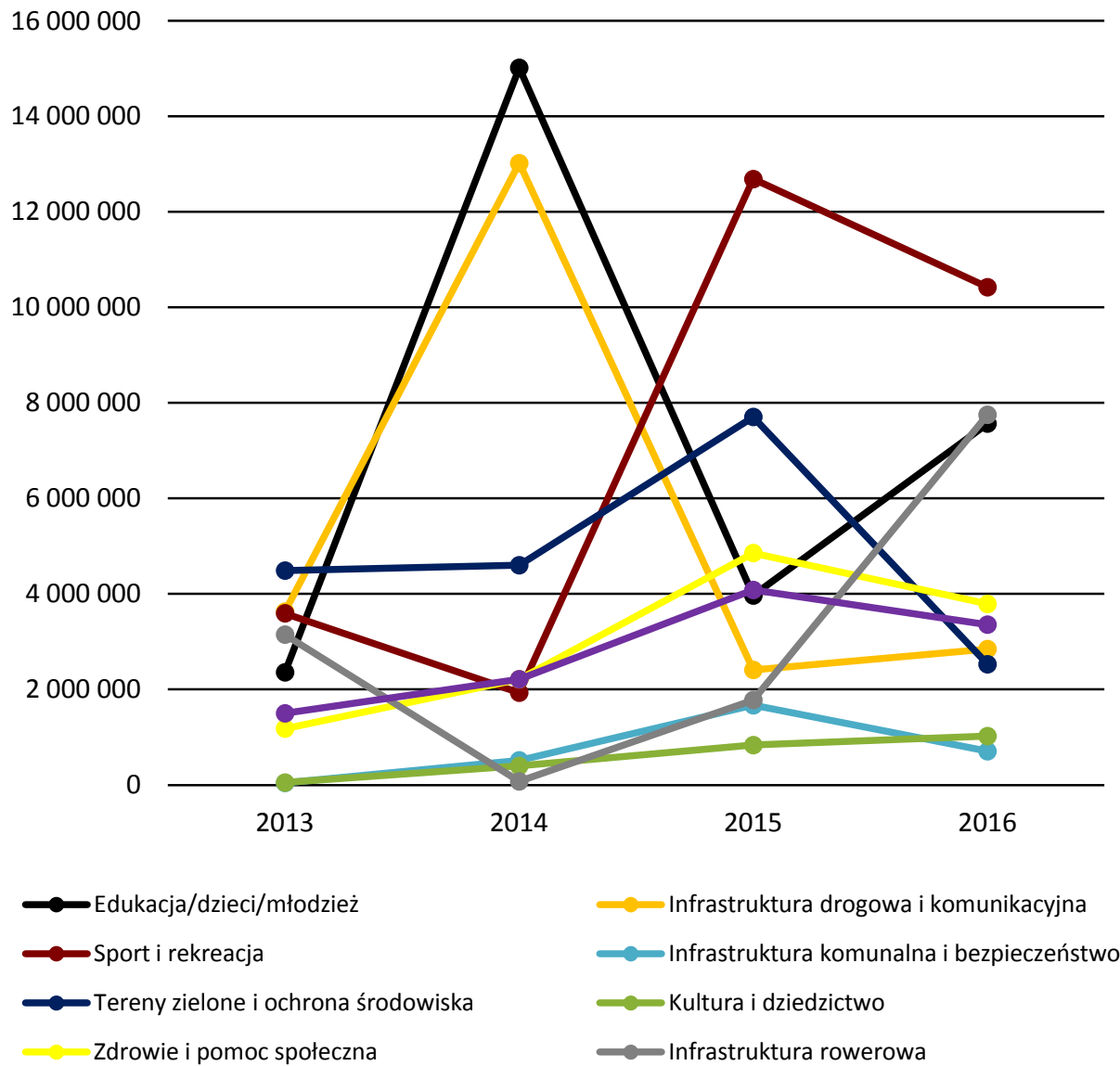

$\longrightarrow$ Inne

Wykres 4. Wartość projektów wybranych do realizacji, ujęcie przedmiotowe

Źródło: opracowanie własne na podstawie danych UMŁ [www2]. 
Analizując informacje zawarte na wykresie 4 można zaobserwować dużą dynamikę zmian wartości realizowanych projektów w poszczególnych latach.

W pierwszej edycji budżetu większość kategorii projektów była realizowana w podobnej wartości. Po zwiększeniu budżetu w 2 edycji z 20 do 40 mln zł., dynamicznie wzrosła wartość projektów z zakresu edukacji, dzieci i młodzieży oraz infrastruktury drogowej i komunikacyjnej, spadła wartość projektów z zakresu sportu i rekreacji oraz infrastruktury rowerowej, a zadania z pozostałych kategorii odnotowały nieznaczny wzrost wartości.

W 3 edycji budżetu zadania, które odnotowały dynamiczny wzrost wartości w poprzednim roku, drastycznie spadły do poziomu porównywalnego do tego z 1 edycji. Znacznie wzrosła zaś wartość projektów z zakresu sportu i rekreacji, a pozostałe kategorie projektów również odnotowały wzrost wartości, choć nie był to wzrost tak gwałtowny.

W ostatniej edycji budżetu największy udział również miały projekty z zakresu sportu i rekreacji. Znacznie wzrosła wartość projektów z zakresu infrastruktury rowerowej oraz edukacji, dzieci i młodzieży, których wartość ukształtowała się na podobnym poziomie. Duży spadek wartości odnotowały projekty z zakresu zieleni i ochrony środowiska. Pozostałe projekty nie odnotowały znaczących zmian wartości w porównaniu do poprzedniej edycji.

W każdej z dotychczasowych edycji budżetu obywatelskiego były projekty, które wyróżniały się pod względem wartości. Zestawienie największych projektów zrealizowanych w ramach budżetu obywatelskiego prezentuje tabela 3.

Analizując informacje zawarte w tab. 3 można zauważyć, że największe projekty w ramach budżetu obywatelskiego dotyczyły głównie obszarów ogólnomiejskich. Wartość większości projektów kształtowała się w granicach 2,5 mln zł. Największy projekt zrealizowany w ramach budżetu obywatelskiego miał wartość ponad 8 milionów złotych, czyli około $20 \%$ całości środków $\mathrm{z}$ budżetu $\mathrm{w}$ danym roku. Cztery spośród dziesięciu największych projektów zostały wybrane w 2 edycji budżetu. Tylko te cztery projekty wyczerpały aż $47 \%$ wszystkich środków przewidzianych na budżet obywatelski w tej edycji. Choć wśród najbardziej wartościowych projektów są zadania zaliczane do wielu różnych kategorii, to większość z nich do projekty infrastrukturalne, dotyczące budowy i modernizacji różnych obiektów użyteczności publicznej oraz zagospodarowania przestrzeni miejskiej. Wszystkie te projekty zostały wybrane dużą liczbą głosów mieszkańców i najczęściej były na pierwszym miejscu w głosowaniu. Oznacza to, że mieszkańcy uznali te projekty za najbardziej potrzebne i warte realizacji. 
Tabela 3. Największe projekty zrealizowane w ramach budżetu obywatelskiego

\begin{tabular}{|c|c|c|c|c|c|c|}
\hline Lp. & Nazwa zadania & $\begin{array}{l}\text { Rodzaj } \\
\text { zadania }\end{array}$ & $\begin{array}{l}\text { Wartość } \\
\text { zadania }\end{array}$ & $\begin{array}{l}\text { Edycja } \\
\text { budżetu }\end{array}$ & $\begin{array}{c}\text { Kategoria } \\
\text { zadania }\end{array}$ & $\begin{array}{l}\text { Liczba } \\
\text { głosów }\end{array}$ \\
\hline 1 & $\begin{array}{l}\text { Aktywizacja dzieci } \\
\text { i młodzieży poprzez po- } \\
\text { prawę infrastruktury } \\
\text { w } 15 \text { łódzkich szkołach }\end{array}$ & $\begin{array}{l}\text { Ogólno- } \\
\text { miejskie }\end{array}$ & 8760119 & 2014 & $\begin{array}{l}\text { Edukacja/ } \\
\text { dzieci/ } \\
\text { młodzież }\end{array}$ & 13764 \\
\hline 2 & $\begin{array}{l}\text { Wymiana nawierzchni } \\
\text { chodników na kostkę } \\
\text { brukową oraz wymiana } \\
\text { nawierzchni miejsc posto- } \\
\text { jowych na kostkę betono- } \\
\text { wą }\end{array}$ & Widzew & 4200000 & 2014 & $\begin{array}{l}\text { Infrastruktura } \\
\text { drogowa } \\
\text { i komunika- } \\
\text { cyjna }\end{array}$ & 4267 \\
\hline 3 & $\begin{array}{l}\text { Przebudowa ul. Rydzowej } \\
\text { na Teofilowie }\end{array}$ & Bałuty & 3700000 & 2014 & $\begin{array}{l}\text { Infrastruktura } \\
\text { drogowa } \\
\text { i komunika- } \\
\text { cyjna }\end{array}$ & 4380 \\
\hline 4 & Łódzki rower miejski & \begin{tabular}{|l}
$\begin{array}{l}\text { Ogólno- } \\
\text { miejskie }\end{array}$ \\
\end{tabular} & 3117500 & 2013 & \begin{tabular}{|l|} 
Infrastruktura \\
rowerowa
\end{tabular} & 8819 \\
\hline 5 & $\begin{array}{l}\text { Poprawa komfortu zwie- } \\
\text { dzania łódzkiego ZOO - } \\
\text { częściowa przebudowa } \\
\text { alejek oraz zieleni w ich } \\
\text { okolicach }\end{array}$ & $\begin{array}{l}\text { Ogólno- } \\
\text { miejskie }\end{array}$ & 2500000 & 2015 & Inne & 11642 \\
\hline 6 & $\begin{array}{l}\text { Lunapark inaczej - stwo- } \\
\text { rzenie nowoczesnej strefy } \\
\text { wypoczynku, rekreacji } \\
\text { i animacji w Parku na } \\
\text { Zdrowiu }\end{array}$ & $\begin{array}{l}\text { Ogólno- } \\
\text { miejskie }\end{array}$ & 2500000 & 2015 & $\begin{array}{l}\text { Sport i rekre- } \\
\text { acja }\end{array}$ & 10438 \\
\hline 7 & $\begin{array}{l}\text { Rekreacja wodna dla } \\
\text { Widzewa - doposażenie } \\
\text { basenu „Anilana”. }\end{array}$ & $\begin{array}{l}\text { Ogólno- } \\
\text { miejskie }\end{array}$ & 2487500 & 2016 & $\begin{array}{l}\text { Sport i rekre- } \\
\text { acja }\end{array}$ & 4771 \\
\hline 8 & $\begin{array}{l}\text { Remont części budynku } \\
\text { przeznaczonego na pierw- } \\
\text { sze stacjonarne hospicjum }\end{array}$ & $\begin{array}{l}\text { Ogólno- } \\
\text { miejskie }\end{array}$ & 2468946 & 2015 & $\begin{array}{l}\text { Zdrowie } \\
\text { i pomoc spo- } \\
\text { łeczna }\end{array}$ & 9536 \\
\hline 9 & $\begin{array}{l}\text { Projekt przywrócenia } \\
\text { hodowli hipopotamów } \\
\text { w łódzkim ZOO }\end{array}$ & $\begin{array}{l}\text { Ogólno- } \\
\text { miejskie }\end{array}$ & 2450000 & 2016 & Inne & 4571 \\
\hline 10 & $\begin{array}{l}\text { Utworzenie parku - Ogro- } \\
\text { dów Jana Karskiego }\end{array}$ & Polesie & 2325000 & 2014 & \begin{tabular}{|l|} 
Tereny zielone \\
i ochrona \\
środowiska
\end{tabular} & 2477 \\
\hline
\end{tabular}

Źródło: opracowanie własne na podstawie danych UMŁ [www2]. 
Wybór tak dużych projektów w ramach budżetu obywatelskiego ma swoje wady i zalety. Duże projekty są niewątpliwie bardziej zauważalne w przestrzeni miejskiej, z reguły służą też dużej grupie mieszkańców, przyczyniają się do promocji budżetu wśród społeczności lokalnej. Ich realizacja wymaga jednak stosowania przepisów o zamówieniach publicznych, przez co cała procedura jest skomplikowana i niekiedy trwa znacznie dłużej niż określony w zasadzie roczności rok budżetowy. Duże projekty angażują także znaczną część środków przewidzianych na daną edycję budżetu, przez co inne projekty, mimo zdobycia porównywalnej liczby głosów mieszkańców, nie mają szans na realizację.

Przeprowadzona analiza dotychczasowych edycji budżetu obywatelskiego pokazała ogromną skalę całego przedsięwzięcia. W ramach budżetu obywatelskiego zrealizowano ponad 400 zadań $\mathrm{z}$ różnych dziedzin życia, o wartości 140 milionów złotych. Co jednak najważniejsze udało się zrealizować nadrzędny cel idei budżetu obywatelskiego, jakim jest aktywizacja mieszkańców, zachęcenie ich do udziału w życiu publicznym oraz wspólnego decydowania o przeznaczeniu publicznych środków.

\section{PODSUMOWANIE}

Analizując instytucję budżetu obywatelskiego od strony teoretycznej, można wywnioskować, że jest on instrumentem angażującym mieszkańców w proces zarządzania środkami publicznymi, jest podstawą do współpracy mieszkańców $\mathrm{z}$ władzami samorządowymi. Jako jedna z metod partycypacji obywatelskiej, budżet partycypacyjny pobudza mieszkańców do aktywnego działania w społeczności lokalnej, ma również wpływ na budowę społeczeństwa obywatelskiego.

Instytucja budżetu partycypacyjnego ma za zadanie przede wszystkim włączenie mieszkańców w proces alokacji środków publicznych w przestrzeni miejskiej. Trzeba jednak pamiętać, że budżet obywatelski angażuje pewną pulę środków finansowych $\mathrm{z}$ budżetu miasta, tym samym mając wpływ - w mniejszym lub większym stopniu - na jego rozwój. Stopień, w jakim budżet obywatelski wpłynie na rozwój miasta, zależy przede wszystkim od mieszkańców i od tego, jakie projekty wybiorą do realizacji. Aby projekty istotnie wpływały na rozwój miasta, muszą być przede wszystkim trwałe, czyli mieć jak najdłuższy okres użyteczności. Ważne jest także, aby projekty były przydatne dla jak największej liczby mieszkańców.

Analiza budżetu obywatelskiego Łodzi od strony praktycznej zdaje się potwierdzać przyjętą hipotezę, iż budżet obywatelski w znacznym stopniu wpłynął na rozwój miasta. Kwota blisko $140 \mathrm{mln}$ zł pozwoliła na realizację wielu trwałych przedsięwzięć, podnoszących jakość życia mieszkańców w różnych dziedzinach życia. W ramach łódzkiego budżetu obywatelskiego realizowane były 
nie tylko duże projekty inwestycyjne, ale również mniejsze, istotne dla konkretnych grup mieszkańców. Z punktu widzenia przydatności realizację małych inwestycji w budżecie obywatelskim można ocenić dwojako: z jednej strony nie są one istotne dla ogółu mieszkańców oraz często blokują realizację innych, bardziej wartościowych przedsięwzięć. $Z$ drugiej strony jednak umacniają więzi w obrębie mniejszych społeczności, co stanowi podstawę do kształtowania świadomego społeczeństwa obywatelskiego. Nasuwa się zatem wniosek, iż wyznacznikiem sukcesu budżetu partycypacyjnego nie zawsze jest wartość realizowanych projektów, a dojrzałe podejmowanie decyzji przez mieszkańców, $\mathrm{z}$ pełną świadomością odpowiedzialności za dokonane wybory.

Przedstawiona w niniejszym artykule analiza budżetu obywatelskiego nie wyczerpuje w całości omawianej problematyki. Brak określonych ram prawnych oraz możliwość indywidualnego dopasowania budżetu do potrzeb miasta sprawia, że trudno jest jednoznacznie określić poprawność zastosowanych rozwiązań. Niemniej jednak, dokonana analiza zdaje się potwierdzać tezę, iż budżet obywatelski, skonstruowany zgodnie z powszechnie obowiązującymi zasadami, jest narzędziem umożliwiającym mieszkańcom realny wpływ na rozwój miasta oraz budującym świadomość społeczną.

\section{BIBLIOGRAFIA}

Aleksandrowicz P., Budżet obywatelski, czyli kieszonkowe dla wyborcy, www.obserwatorfinansowy.pl/forma/analizy/budzet-obywtaelski [dostęp: 11.06.2013].

Dias N., 2014, Hope for Democracy. 25 Years of Participatory Budgeting Worldwide, In Loco Association, São Brás de Alportel, Portugalia.

Dolewka Z., 2015, Budżet partycypacyjny $w$ teorii $i$ w praktyce, „Prace Naukowe Uniwersytetu Ekonomicznego we Wrocławiu", nr 408, Wydawnictwo Uniwersytetu Ekonomicznego we Wrocławiu, Wrocław.

Goldfrank B., 2007, Lessons from Latin American Experience in Participatory Budgeting, [w:] A. Shah, Participatory Budgeting. Public Sector Governance and Accountability Series, World Bank Publications, Waszyngton.

Kalisiak-Mędelska M., 2016, Budżet obywatelski w Polsce. Analiza porównawcza Łodzi i Poznania, „Prace Naukowe Uniwersytetu Ekonomicznego we Wrocławiu”, nr 443, Wydawnictwo Uniwersytetu Ekonomicznego we Wrocławiu, Wrocław.

Kębłowski W., 2013, Budżet partycypacyjny. Krótka historia obsługi, Instytut Obywatelski, Warszawa.

Kraszewski D., Mojkowski K., 2014, Budżet obywatelski w Polsce, Fundacja im. Stefana Batorego, Warszawa.

Łukomska-Szarek J., 2014, Budżetowanie partycypacyjne jako instrument wspótzarządzania sfera publiczna, „Nierówności Społeczne a Wzrost Gospodarczy”, nr 40, Wydawnictwo Uniwersytetu Rzeszowskiego, Rzeszów.

Po co nam budżet obywatelski?, rozmowa z Jarosławem Makowskim, dyrektorem Instytutu Obywatelskiego, www.instytutobywatelski.pl [dostęp: 29.08.2013]. 
Rytel-Warzocha A., 2010, Partycypacja spoleczna w sprawach budżetowych. Model Porto Alegre jako pierwowzór rozwiąań europejskich, „Przegląd Prawa Konstytucyjnego”, nr 1, Wydawnictwo Adam Marszałek, Torun.

Sorychta-Wojszczyk B., 2015, Uwarunkowania wykorzystania budżetu obywatelskiego w administracji publicznej w Polsce, ,Zeszyty Naukowe Politechniki Śląskiej”, nr 1928, Wydawnictwo Politechniki Śląskiej, Gliwice.

Serzysko E. (red.), 2015, Standardy procesów budżetu partycypacyjnego w Polsce, Fundacja Pracownia Badań i Innowacji Społecznych „Stocznia”, Warszawa.

Szaranowicz-Kusz M., 2014, Budżet partycypacyjny. Jak mieszkańcy mogq współdecydować o budżecie miasta, Fundacja Pole Dialogu, Warszawa.

Wampler B., 2007, A Guide to Participatory Budgeting, [w:] A. Shah, Participatory Budgeting. Public Sector Governance and Accountability Series, World Bank Publications, Waszyngton.

[www 1] http://sejm.gov.pl/Sejm7.nsf/BASLeksykon.xsp?id=667DCF4F24778F74C1257A71003 0C2E9\&litera=B [dostęp: 07.02.2018].

[www 2] https://uml.lodz.pl/dla-mieszkancow/lodzianie-decyduja/budzet-obywatelski/ [dostęp: 07.02.2018].

[www 3] https://bip.uml.lodz.pl/miasto/budzet-miasta/ [dostęp: 07.02.2018].

[www 4] http://lodz.stat.gov.pl/dane-o-wojewodztwie/stolica-wojewodztwa-1323/ [dostęp: 07.02.2018].

\title{
THE INSTITUTION OF THE PARTICIPATORY BUDGET AS A TOOL OF LOCAL GOVERNMENT DEVELOPMENT
}

\begin{abstract}
The participatory budget is considered one of the best tools that takes into account residents' preferences in the process of managing public funds. It is an instrument that allows residents to co-decide on the direction of spending funds from the local government budget. The article attempts to determine the impact of the participatory budget institution on the development of the local government unit. For this purpose, four editions of the participatory budget of the city of Lodz, conducted in 2013-2016, were analyzed. Particular attention was paid to the budgeting principles, types of executed tasks and directions of spending funds. Finally, the conclusions drawn from the conducted analysis are presented, which confirm that the participatory budget is a tool affecting the development of local self-government.
\end{abstract}

Keywords: participatory budgeting, social participation, local government. 